\title{
Foes, friends or indifferent players? \\ Assessing national energy strategies and possible agenda for cooperation between Brazil and Russia*
}

\author{
B. M. Jubran, V. Jeifets \\ State Department of Planning, Administration and Budget of Rio Grande do Sul, \\ 1501, Avenida Borges de Medeiros, CEP 90020-020, Porto Alegre (RS), Brazil \\ St. Petersburg State University, \\ 7-9, Universitetskaya nab., St. Petersburg, 199034, Russian Federation
}

For citation: Jubran B. M., Jeifets V. Foes, friends or indifferent players? Assessing national energy strategies and possible agenda for cooperation between Brazil and Russia. Vestnik of Saint Petersburg University. International Relations, 2019, vol. 12, issue 2, pp. 181-197.

https://doi.org/10.21638/11701/spbu06.2019.205

This article aims at analyzing the actual and potential cooperation between Brazil and Russia - two BRICS countries - in energy issues. Addressing energy security in global affairs and national strategies is quite obvious due to its centrality in shaping contemporary civilization. While energy is also vital for International Relations and for the foreign policy of particular countries, the topic remains quite underdeveloped in Brazil-Russia relations. This contradiction is the main problem raised in the article. There are two main lines of explanation for that question. The first one implies that cooperation between Brazil and Russia is hindered due to poor legal foundations in the energy sector and constant government interference in the business environment in both nations. The second rationale states that both nations allegedly do not share similar interests, or even behave as competitors in each other's or third markets, as they have been suppliers of energy in the global market. We shall advance the third line of argumentation, which contends that even if previous arguments are valid, the role of other players - either foreign governments or private enterprises - should not be underrated to understand possible limitations and setbacks in bilateral relations, in particular in energy matters. Moreover, lack of clarity and definition in energy policy and security is perhaps more convincing than constant government interference, especially in Brazil, and to a lesser extent, Russia.

Keywords: Russia, Brazil, BRICS, energy security, bilateral relations.

\section{Introduction}

In the common sense, energy plays a central role in everyday life of individuals, organizations, states, and in technological race among these actors in current civilization. Paradoxically, its study and theorization in the area of International Relations (IR) and Foreign Policy Analysis (FPA) remains underdeveloped. The concept of energy security, which is perhaps a good starting point for students of both IR and FPA, can be understood not exactly as the ability of a state to internalize all its energy supplies, but as the capacity

* The article was prepared within the marks of the research grant provided by the Russian Foundation for Basic Research (RFFI), Grant No. 19-014-00042 (Latin America in the New World Order: perspectivas and challenges).

(c) Санкт-Петербургский государственный университет, 2019 
of an actor to control its sources, distribution mechanisms and to assure that the energy deliveries, either external or internal, remain stable, predictable and at a sustainable cost in economic, social and environmental terms [1].

While energy security is certainly central for every national foreign policy, in the case of Russia that connection is certainly quite clear and broadly explored in scholar and especially in media outlets. In Brazil, the issue is still underscored, despite its obvious importance since the oil shocks in the 1970s and the discoveries of large oil reserves in the 2000s. Despite the political engagement between both nations since the 2000s, and the relevance of energy in their foreign policies, the issue remains largely underdeveloped in bilateral relations. This contradiction is the main problematic raised in the article.

To address that question, this article shall briefly describe the role of energy security in external interaction of Russia and of Brazil in its first and second sections. The work will assess vulnerabilities and opportunities of each nation not only by determining if it is an overall exporter or importer of energy products, but also how is the composition of its energy matrix, if it is able to provide proper use of energy to fulfill its own consumption requirements (including refining in the case of oil), as well who are its main foreign partners in energy trade. The third part present the current situation of energy cooperation between both countries in bilateral projects, whereas the fourth and last section analyzes their political interests in a broader sense, with particular attention to BRICS and propose some considerations on future developments in their interaction by taking into account the recent changes in Brazilian domestic scenario.

\section{Energy and National energy strategy of Russia}

The very idea of pursuing a long-term and objective strategy is well established in the Russian government. The first post-Soviet document on energy strategy, published in 2003 and aiming towards the year 2020, has been re-issued in 2009. An upgraded version directed towards 2035, whose enactment is still pending, states that [the policy document] "shall be updated not less than once every five years" [9].

The draft version of the 2035 Energy Strategy recognizes the relevance of energy and fuels sector to sustain Russian economy and national security, as follows: "The role of energy industry in corresponds to one third of overall investments in fixed capital, around a half in federal government's budget around, and more than a half in Russian exports (in terms of value). Its contribution for the GDP corresponds to $25-26 \%$, while not less than $4 \%$ of economically active population" [9].

In general terms, Russia is well positioned in energy sector. In the short and even medium terms, its production level is compatible to its enormous natural reserves in every relevant source, assuring a relatively comfortable situation of the nation in the matter. Despite high production levels in many segments, especially in oil and gas, the durability of proved reserves of non-renewable sources is roughly comparable to global averages, as shown in Table 1.

The relative endurance of Russian fossil sources over next decades may grant a smooth energy transition towards renewables, nuclear and other cleaner sources. It also implies that current economic structure grounded on extensive exploitation of natural resources may endure for additional years, if commodities' prices and markets remain free of dramatic turbulences and even if new reserves are not discovered in Russian territory. 
Table 1. Russia: durability of non-renewable sources

\begin{tabular}{lccccccc}
\hline & $\begin{array}{c}\text { Volume } \\
\text { Unity }\end{array}$ & $\begin{array}{c}\text { Proven } \\
\text { reserves } \\
(\mathbf{2 0 1 7})\end{array}$ & $\begin{array}{c}\text { Share of } \\
\text { global } \\
\text { reser- } \\
\text { ves, } \%\end{array}$ & $\begin{array}{c}\text { Volume } \\
\text { unity }\end{array}$ & $\begin{array}{c}\text { Production } \\
(\mathbf{2 0 1 7})\end{array}$ & $\begin{array}{c}\text { Ratio } \\
\text { (Reserves: } \\
\text { Production) }\end{array}$ & $\begin{array}{c}\text { World } \\
\text { ratio } \\
\text { average }\end{array}$ \\
\hline & $\begin{array}{c}\text { Thousand } \\
\text { million } \\
\text { barrels }\end{array}$ & 106.2 & 6.3 & $\begin{array}{c}\text { Thousand } \\
\text { barrels } \\
\text { per day }\end{array}$ & 11257.3 & 25.8 & 50.2 \\
\hline & $\begin{array}{c}\text { Trillion } \\
\text { cubic } \\
\text { meters }\end{array}$ & 35.0 & 18.1 & $\begin{array}{c}\text { Billion } \\
\text { cubic } \\
\text { metres }\end{array}$ & 635.6 & 55.0 & 52.6 \\
\hline Coal & $\begin{array}{c}\text { Million } \\
\text { tonnes }\end{array}$ & 160364.0 & 15.5 & $\begin{array}{c}\text { Million } \\
\text { tonnes }\end{array}$ & 411.2 & 391.1 & 134.5 \\
\hline
\end{tabular}

Source: [12].

However, a deeper insight exposes vulnerable points in energy sector, especially with respect to Russia's interaction with foreign players. While the nation is a major supplier of energy, its incomes remain concentrated in oil exports, with low aggregated value and still mostly directly to European markets. In 2017, total oil exports accounted for roughly half of Russian exports in terms of value, while crude oil represented almost $60 \%$ of that proportion (or more than a third of overall exports); natural gas responded for $11 \%$ of total exports [10]. Oil and oil products produced in Russia are still directly mostly to European markets, although Chinese and other Asian markets have been increasing their share in Russian oil exports, especially since the crisis in the EU-Russia relations had started in 2013-2014 because of the events in Ukraine. In the case of natural gas, the picture is even more complicated: while several European politicians fear the high dependency of gas extracted in Russia or transported through pipelines crossing Russia from Central Asia and the Caucasus, Moscow has run not only the risk of relying in one regional player - the European Union - but also of requiring constant stability and collaboration of all transit countries, notably Ukraine. In late 2000s, before the implementation of Nord Stream project that connects Russian suppliers to Germany through the Baltic Sea, Ukrainian routes delivered about $80 \%$ of gas extracted in Russia or drained from Central Asian countries [11].

The imposition of economic sanction by many Western nations against Moscow since the Ukrainian crisis in 2014 economic relations has put Russian energy industry under pressure. Economic ties between Russia and Western nations (particularly the European Union and the United States) have been severed on both directions, impelling the Russian government to engage with Asian countries, notably China. Still in 2014, Moscow and Beijing agreed upon enhancing trade activity, in which energy would play an invigorating role in economic relations.

A second aspect of vulnerability in Russian energy sector is the high dependence in one type of source, natural gas, which has been increasing in terms of importance since the Soviet times in detriment of oil and coal (Fig. 1). However, that fragility is not severe, as the nation is a net exporter of gas (although a tiny proportion of domestic consumption is imported from Central Asian countries [12, p.34]), and proved national reserves are 
large enough to sustain current level of production for the next five decades, if no reserves are discovered (Table 1). This advantage might provide time for government and private actors to readapt themselves towards renewable and more sustainable sources. Natural gas is generally preferred over oil due to lower economic costs and lower environmental implications, especially in terms of $\mathrm{CO}^{2}$ emissions.

Beyond those two quantitative vulnerabilities, there is a pervasive understanding not only in academic and professional circles, but also within the government that energy industry suffers a chronic problem of relative backwardness in terms of technology and efficiency in comparison to developed markets. The Energy Strategy to 2035 not only recognizes it, but also correlates such shortcoming with a depressed level of investments and, consequently, a lower economic performance of the sector in Russia vis-à-vis other nations [9]. Given the prevailing competitive logic of current global economy, Russian position in energy markets may become under threat due to the strengthening of traditional competitors (as US and Arab energy companies) and the emergence of big players (in particular in Asia, Australia and Latin America). In conjunction with market trends, political disputes sharpen those menaces to Russian energy industries. The imposition of a series of sanctions to Russian citizens and companies hampers their access to credit and technologies still only available in the West and directly challenges the nation's status as an energy global superpower in medium and long run.

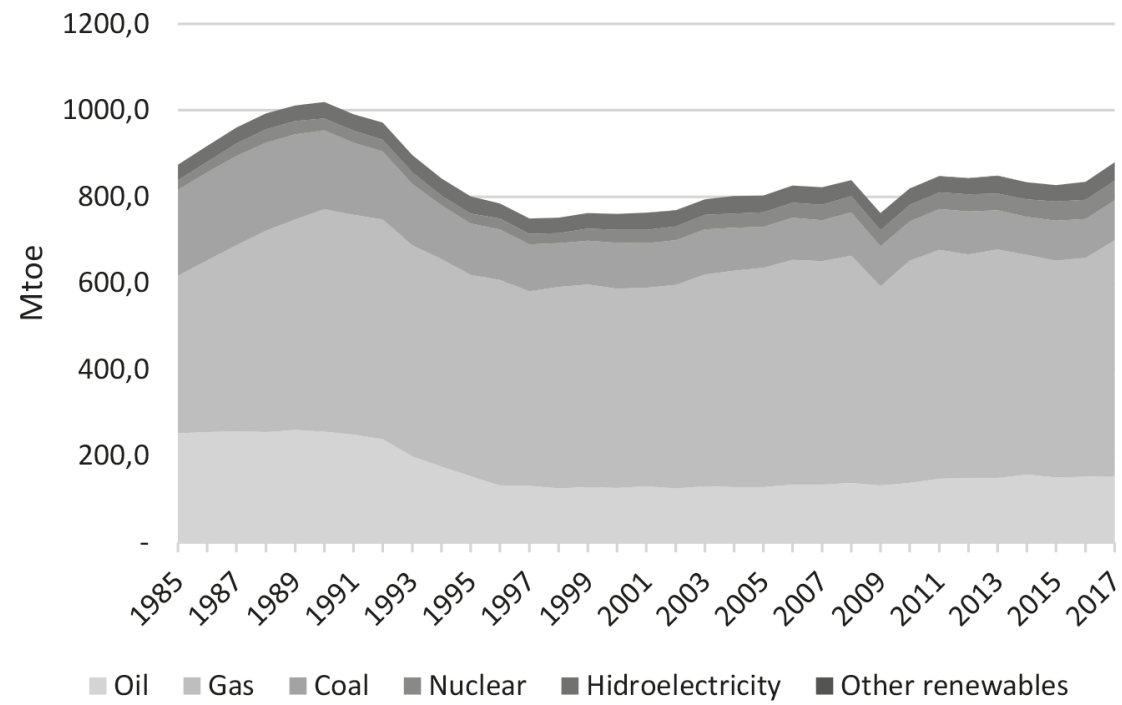

Fig. 1. Evolution of Primary Energy Consumption in Russia by source (1985-2017). Source: [12]

Progressive rapprochement with countries that have not been engaging in the imposition of sanctions may partially reduce those vulnerabilities. Deepening relations with China and other East Asian countries is a strategic choice that may simultaneously reduce the dominance of exports towards Western ports and attract investments to revamp the infrastructure of extraction and distribution of particular fuels as explicitly cited in the Strategy [9]. Moreover, developing multifaceted ties with developing countries in Africa 
and Latin America may not only increase Russian exports, but also expand the share of high value-aggregated products, such as refined oil and other oil products, one of the goals of the Strategy towards 2035 [9].

Among other objectives of Russian energy industry, it can be also stressed: enhancement of competitiveness in Russian energy industry in the global market; easing of access to energy for domestic consumers; decrease in energetic intensity in absolute and relative terms; promotion of more environment-friendly technologies in the sector; and development of renewable sources [9].

Over the recent years, oil sector in Russia has consistently moved towards the increase of aggregated-value along the chain production. After 2008, international oil price has shown inconsistent trends, impacting severely crude oil exporters around the world, including Russia. Since then, oil sector in Russia has strived to increase aggregated-value of oil exports, in particular fuel oil (43\% up from 2008 to 2013), while also reducing the amount of crude oil exported ( $8 \%$ down in the same period). In terms of production, although the share of oil in Russia's energy matrix has witnessed a relative reduction, its extraction increased $8 \%$ in volume in that period, thanks to the operationalization of fields in Eastern Siberia and Yakutia. Refining output has expanded even more dramatically in $23 \%$ over that period [9]. In line with the declared objective of reducing dependency in exports westwards, Russia, through its state-owned company Transneft, has completed two sections of the Eastern Siberia-Pacific Ocean pipeline (ESPO) and an additional branch towards the Chinese town of Daqing. In the West, the Baltic Pipeline System II has been implemented in order to bypass the territory of transitional countries in Eastern Europe, another source of vulnerability.

Despite the advances, oil industry in Russia still faces the volatility in international prices combined with the entry not only of new exporters, not to mention the explicit intention of many partners (in particular in Europe) to reduce oil imports from Russia. Moreover, new oil fields in Russia are being found in remote areas, inflating costs of extraction and distribution. The necessity of drilling farther and deeper also requires the development of certain techniques still not in possession of Russian companies.

From 2010 to 2016, natural gas output in Russia underwent some oscillations, and in 2017 it expanded considerably. As in case of oil sector, the extraction of natural gas has been sustained through the establishment of new extraction fields, mainly in the Arctic and Sub-Arctic regions. In case of gas, the relevance of Europe for Russia has been much more acute than in oil exports, deepening the mutual dependence and vulnerability between both partners. Despite the attempts of reducing mutual vulnerability, Russia's relevance for European Union members has maintained or even increased amid political turbulence since 2014 in case of gas, oil and coal (Table 2). The completion of Nord Stream-2, connecting Russia to Germany through the Baltic Sea, shall increase those figures and further reducing the bargaining power of in-between countries.

While the deliveries for some countries such as Ukraine have receded seriously, the promise of inauguration and exploitation of new routes eastwards, particularly to China and other Asian countries ${ }^{1}$ may not only increase dividends of exports in the sector, but also augment Russia's leverage in determining the price of the fuel.

1 Sila Sibiri (The Power of Siberia), a gas pipeline connecting Yakutia fields to Vladivostok, with a direct branch into China, shall be inaugurated in 2019; Sakhalin-Vladivostok gas pipeline has been explored since 2011. 


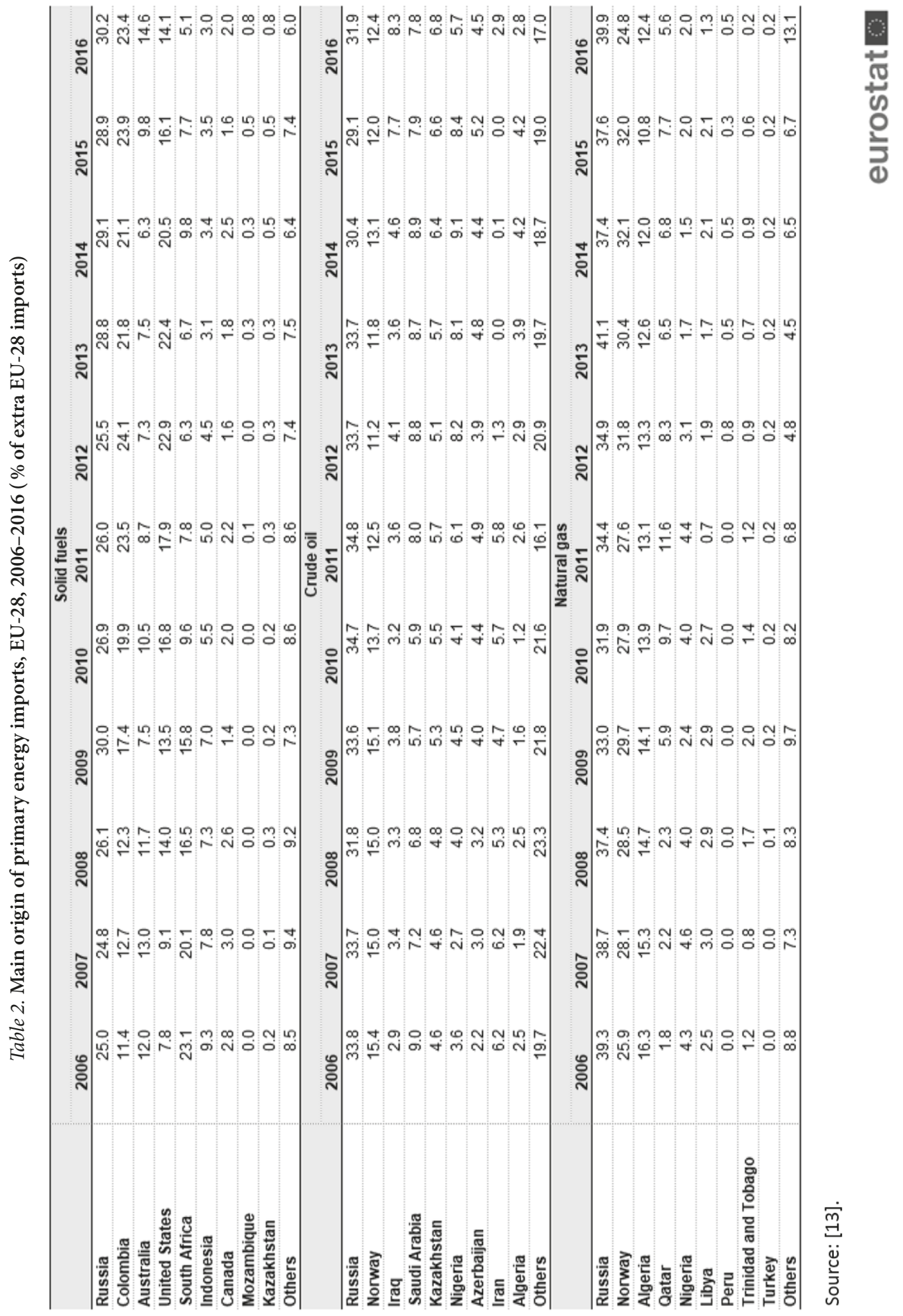




\section{Energy and National energy strategy of Brazil}

Although Brazilian energy industry has been long appraised due to the high share of renewables in its matrix, there is a difficulty to create a consensus towards a clear longterm national strategy, in opposition to the Russian case [2]. Domestic disputes over basic questions, which persisted during most of the $20^{\text {th }}$ century and has prolonged into the beginning of the next century, has partially shaped the current energy policy. Furthermore, some opinions doubt about the very possibility of implementing a cohesive and logic strategy in a part of the world where US influence has been hegemonic and averse either to local autonomous powers or to interference of both China and Russia [8].

It is much harder to identify a clear and long-standing strategy for the Brazilian energy industry, although it is possible to point out some continuities since at least the mid$20^{\text {th }}$ century. Perhaps the quest for energetic autonomy (in terms of supply) is a recurring pattern over decades. External shocks in the supply of energy, especially in oil trade, was part of the reasoning for reducing dependency from foreign deliveries; the memory of fuel shortage in the country during the Second World War lay the basis for enacting policies to protect national energy industry.

Autonomy was conceived not only as the maximization of internal supply of energy, but also the control over production and distribution processes by the government. The foundation of major state-owned companies in the sector proves that assumption: Petrobras (oil industry, created in 1953), Eletrobras (electricity, founded in 1962); several federative states also followed suit and created local energy entities. ${ }^{2}$

However, the focus on autonomy waned over the following decades. Although successive administrations worked to enhance domestic capabilities, in particular through hydropower, oil demand expanded quite rapidly due to prioritization of road system and popularization of automobile industry in detriment of other modes of transportation systems. In mid-1970s, $45 \%$ of energy consumed in Brazil was provided by imports [14]. Meanwhile, electricity was being produced mostly through hydropower, making the source responsible for three-quarters of consumed electricity in the country. Despite such an over-reliance on one single source, the policy was calculated due to extensive availability of Brazilian rivers, low costs of implementation and the relatively low impact on environment when compared to other resources [2].

Sudden rise in international price in 1973 and even more acutely in 1979 appalled government officials due to the high level of vulnerability of national energy security to external events. Many policies intended to restore autonomy by reducing oil imports in domestic consumption, increasing the share of alternative sources available in the country (hydroelectricity, biomass and ethanol) (Fig. 2), and enhancing national oil production (Fig. 3). The increase in domestic supply was possible thanks to partnerships between Petrobras and Brazilian universities and research institutes, which eventually developed new technologies that allowed extracting oil in deep-water fields in the Atlantic, already in the 1970s.

${ }^{2}$ For instance, Eletropaulo (energy delivery) and Companhia Energética de São Paulo (energy generation), in São Paulo state; Companhia Energética de Minas Gerais (CEMIG), Minas Gerais state; Companhia Estadual de Energia Elétrica (CEEE) in Rio Grande do Sul state, among others. Most state-level companies though were put under private control in the 1990s. 


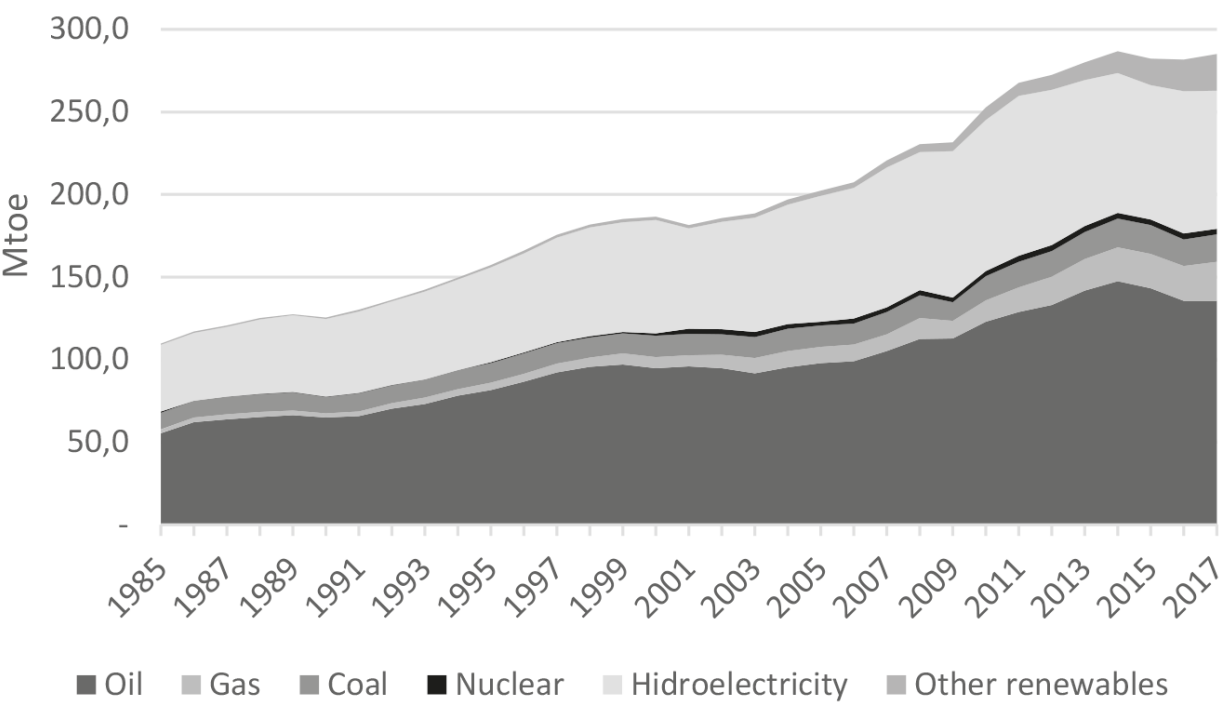

Fig. 2. Evolution of Primary Energy Consumption in Brazil by source (1985-2017). Source: [12]

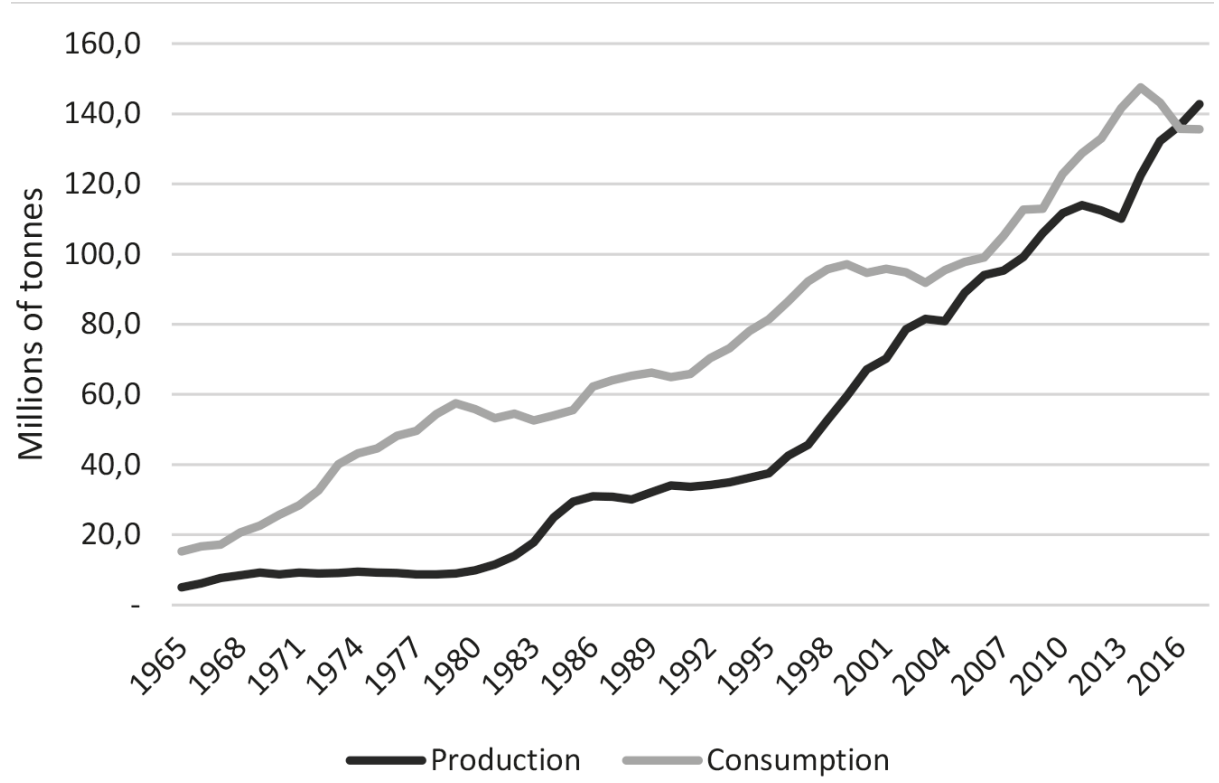

Fig. 3. Production and Consumption of oil in Brazil (1965-2017). Source: [12]

It is possible to infer that, for many years, vulnerability has been conceived largely in terms of how much of domestic consumption depended on direct energy imports. However, as observed in Russian case, energy security also involves other relevant variables and is constantly subject to new categories and definitions. In addition to this point, depending on foreign exports is not exactly a problem when the supply chain is under an international in- 


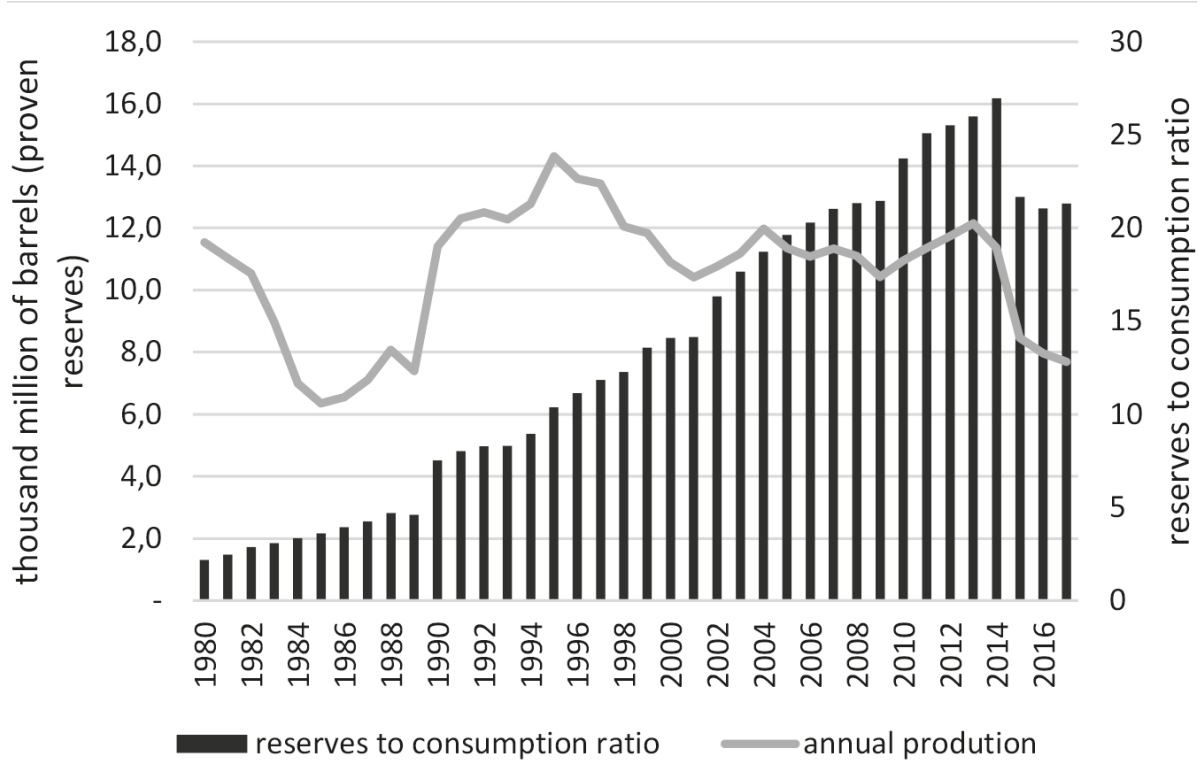

Fig. 4. Reserves to production ratio in Brazil. Source: [15]

tegration framework ${ }^{3}$. The importer nation may exert implicit or direct control over abroad reserves ${ }^{4}$. Beyond direct dependence of external 'independent' deliveries, strategic vulnerability also encompasses proven reserves-production ratio (or 'life expectancy of reserves'), ecological damage to population, innovation inputs in the sector, technological control over energy processes, and also cost-benefit of resources, among other factors.

Although Brazil has managed to reduce significantly oil imports after 1970, while also promoting diversification of its matrix, two important shortcomings became more and more apparent over the following decades. Firstly, the country did not saw an upsurge in the discovery of new reserves of oil until the 1990s, thus 'depleting' the existing ones and leading reserves-to-production ratio to a threatening level although the discovery of reserves in the offshore pre-salt layer managed to partially reverse the trend (Fig. 4). In order to secure proper supply, the company also strived to establish and diversify partnerships with oil-exporting countries from different regions, such as Libya, Iraq, Angola and Venezuela. The exploitation of pre-salt layer in the 2010s also reduced the demand on crude oil imports.

Due to destabilization in many supplying nations $s^{5}$ and poor economic performance of Brazil in the 1990s, many investments were curtailed and the company was partially privatized. During neoliberal presidencies of Fernando Collor de Melo (1990-1992) and Fernando Henrique Cardoso (1995-2002) autonomy was abdicated in favor of opening the energy

${ }^{3}$ For example, US dependence on Canadian oil is not a serious problem for the former once both nations are highly integrated in economic, social and political domains).

4 The United Kingdom (and after the US) used to rely on vast oil resources of Persia due to the heavy influence over the Asian nation, what can be considered as a clear an example of political (and military) control of foreign energy resources.

${ }^{5}$ Brazil used to have a solid partnership with Iraq. The Arabic nation was not only the major oil supplier to Brazil, but also a big purchaser of Brazilian manufactured goods until the Gulf Crisis in 1990. 
sector to private and foreign entities, especially the generation of electricity. The move was expected to increase energy supply, to promote economic competitiveness in the sector, induce more efficiency and attract foreign capital capable of promoting local infrastructure and bringing new technologies. The restructuring involved deregulation of the sector, the end of Petrobras monopoly in many oil-related activities, and the creation of monitoring agencies. However, the results were much meager than expected, as investments were not sufficient to avoid a major collapse of Brazilian electricity system in 2001 [14].

By that time, reviewing the national energy strategy started to be demanded by many specialists and the public opinion. The election of Lula da Silva in 2002, himself critic of proprivatization stance in the 1990s, was the culmination of that movement. Although his administrations did not restore the pure autonomist trend of the military dictatorship (19641985), Da Silva sought to strengthen national capabilities in certain sectors, especially in oil sector. The solid elevation in oil prices in the 2000s allowed Petrobras not only to increase its revenues, but also to perform investments in new oil fields and refining capacity, leading to the balancing between production and consumption in the next decade. Also, the government acted to reduce over-reliance on hydroelectricity by installing thermoelectric plants in every region, even though the former remained, by far, as the main source of electricity.

Over the last few decades, boosting regional energy integration has been a common ground pursued by successive federal administrations, despite their divergences in political orientation. Therefore, insistence in enhancing domestic self-reliance has been relativized in favor of deepening ties with neighboring countries, while also not completely relinquishing trade with other countries, particularly in North America and the Middle East. Still during last period of authoritarian regime, Brazilian government financed and built Itaipu Hydropower, the most powerful plant at time, in the border with Paraguay on Parana River. In 1997, a gas pipeline connecting extracting areas in Bolivia to major Center-South Brazilian metropolises was inaugurated. In 2017, natural gas, which was the third more relevant source in energy matrix, was partially provided from Bolivia (roughly $25 \%$ ), while the remaining was obtained from domestic reserves.

Although energy was an obvious central topic for Brazilian administrations, not until 2007 the nation managed to publish an official report on the industry aimed at planification. The National Plan of Energy, just as Russia's Strategy, analyzes the situation in each source, forecasts scenarios towards 2030 and proposes strategies to cope with vulnerabilities and weaknesses in that realm. The scope of the plan is wider and more detailed than its Russian counterpart: it not only reiterates objectives and policies and strategies for energy industry, but also foresees different scenarios of economic and demographic growth, to which given energy strategy shall respond.In the same context, Empresa de Pesquisa Energética (EPE) was created in order assist the government, including planning assessment, provision of data and statistics, elaboration of relevant analysis in all energy segments, including economic, environmental and social costs [21].The institution, together with Ministry of Mining and Energy (MME), was directly involved in designing the 2030 Energy Plan, and has been committed to deliver an updated version, the 2050 Energy Plan, beyond the making of other regular reports on the sector. ${ }^{6}$

One major objective of National Plan towards 2030 is to promote diversification in energy matrix, reducing the role of oil and its products, while increasing the share

${ }^{6}$ For instance, the Energetic Outlook and the Statistical Yearbook, both issued in a yearly basis. 
of renewables, uranium and even some fossil sources (gas and coal), but the use of renewables were expected to increase in relative terms, though fossil fuels shall prevail $(53,4 \%)$ in 2030 . Domestic sources are expected to continue supplying around $90 \%$ of energy requirements. Energy intensity by GDP unit ought to be reduced in $5 \%$ over the period.

In current energy matrix, oil has been the most important energy source and shall maintain that prevalence over the next decades, according to 2030 National Energy Plan. While oil sector has managed to reduce foreign reliance since the 1970s by enhancing domestic production, it is also true that fostering the consumption of alternative fuels, namely ethanol and biodiesel more recently also contributed in that direction. In mid2010s, the nation has become a net exporter of oil, thanks not only to the maturing of infrastructure investments, but also due to a severe economic depression between 2015 and 2016. Due to technical aspects, Brazil imported $8,1 \%$ of oil processed in its refineries in 2017 [16]; almost half of imported volume is originated from Saudi Arabia (50,6 \%), followed by Algeria (23\%) [15, p. 10], what implies an accentuated vulnerability due not only to geographic concentration, but also to heavy reliance on trade routes prone to geopolitical and security issues, such as piracy in Indic Ocean, chronic conflicts on African and Yemeni shores of Aden Sea, and possible military confrontation around Ormuz Strait between Saudi Arabia and Iran.

While the country is a net exporter of crude oil, the same cannot be applied to refined oil, which is a chronic trouble for Brazilian policymakers. The adoption of a pro-market approach since 2015 due to recession and corruption scandals has further aggravated the problem. In 2013, utilization factor of Brazilian refineries peaked $97 \%$; in 2017, the figured decreased to $76 \%$ [12]. To compensate declining domestic production, Brazil has increased imports of oil products. From 2016 to 2017, imports soared $30 \%$ in volume [12, p. 14]; while more than half of imported amount originated from the US, implying vulnerability in terms of predominant supplier.

A major obstacle in Brazilian energy sector is the inconsistency in policy planning and implementation. The case of Petrobras along the 2010s illustrate the problem: while its Business Plan in 2014 envisaged to reach daily production of 4.2 million barrels by 2020 , the 2015 Plan curbed that figure to only 2.8 million barrels per day, while also foreseeing sharp cuts in investments and sales of assets [3]. The same can be applied to other resources. Nuclear energy, which has been under consideration among Brazilian authorities even before the military regime due to the availability of uranium in the country, witnessed a major advance in 1970s with the construction of two plants near Rio de Janeiro (Angra 1 and 2). Economic turbulence, budget shortcomings and the abrupt policy reorientation in 1990 delayed the completion of Angra-2 to 2001 and have postponed several times the inauguration of Angra-3. There have been projects on wind and solar energy, but their high cost and lack of interest in Jair Bolsonaro's administration may difficult their implantation over the territory in the future.

\section{Energy agenda in bilateral relations between Brazil and Russia}

Brazil was never the key economic partner for the Soviet Union; Argentina and Communist Cuba hold the pole positions in terms of trade with the USSR. Trade links were established in 1959 after an official Brazilian mission paid visit to Moscow and negotiated 
the commercialization of Soviet oil in change of Brazilian agricultural products ${ }^{7}$, even before the restoration of diplomatic relations in 1961 [4].

In the 1970s, energy cooperation became also technological, with the provision of Soviet-made turbines for Sobradinho hydroelectric plant in Bahia state through compensation system, as trade balance always favored the Brazilian side. Brazilian major contractor Odebrecht and Soviet Technopromeksport also gathered to develop and build hydroelectric plant of Capanda, in Angola [4].

The fall of the Soviet Union in 1991, and the political and economic instabilities in Brazil and in the new Russia along the 1990s postponed or stalled several projects. Neoliberal reforms targeted inflation control diminution of primary deficits in both nations, but also foresaw budget cuts for implementing new projects and standstill in enhancing energy capabilities. Even oil crude trade was severely hit by Brazilian reduced demand ${ }^{8}$, whereas the scrapped infrastructure of the oil sector also affected Russian exports. Moreover, lack of reciprocal interest between Brazilian and Russian hindered a serious breakthrough in every single aspect of bilateral dialogue, including energy talks, especially under Collor de Melo presidency (1990-1992) and Andrey Kozyrev's Ministry of Foreign Affairs (1992-1996) [5].

The main advance was the establishment in 1997 of the High-Level Commission, which is chaired by the Russian Prime-Minister and the Brazilian Vice-President, with the purpose of discussing basic provisions of bilateral relations, and also the Intergovernmental Commission for Cooperation, which addresses specific cooperation projects. Despite the progress in framework, talks halt due to the financial crisis in Russia, which led to a spiral of political instability ${ }^{9}$. Brazil was also hit by a major currency devaluation in 1999, harming nation's ability to sustain international economic deals. Another significant fact was the 1994 agreement on the pacific uses of nuclear energy, which stipulated topics and means of cooperation, as well as the national executive agencies, Rosatom (Russia) and National Commission for Nuclear Energy (Brazil), but due to the aforementioned problems, the cooperation remained mostly on paper.

An interesting characteristic of the 2000s was the process of familiarization between representatives of both nations. In several occasions, negotiators did share many points of view on principles of cooperation and the desirability of a balanced and mutually beneficial partnership, but disagreed on how to give concrete steps to execute the projects. While there was interest to promote cooperation, including in energy questions, Russian representatives expected primarily to commercialize their technologic portfolio to their Brazilian counterparts, who were eager to develop joint horizontal partnerships in development, production and technology-sharing [5].

Nuclear technicians from both nations were able to discuss and even to propose some projects in several rounds of negotiation. In the opinion of Brazilian diplomats, the main reason for poor results lay on the fragilities in Brazilian nuclear program, and not in divergent views between both sides. President Cardoso's trip to Russia in early 2002 was

7 In 1947, two years after officially recognizing the Soviet Union, Brazilian government unilaterally broke its ties with Moscow after a minor incident involving a criticism on Brazil in an issue of Literaturnaya Gazeta published in the USSR.

${ }^{8}$ In this case, not only due economic difficulties, but also to the decision of reducing foreign oil imports in favor of domestic production, as seen in the previous section.

9 Only in 1998 and 1999, five different individuals were nominated as Prime Minister of Russia. 
remarkable to its political outcomes ${ }^{10}$, but did not improve bilateral collaboration in economic and technology domains in a meaningful fashion [5].

In 2004, for the first time representatives of Brazilian Petrobras and Russian Gazprom, met to prospect possibilities of cooperation, including Russian participation in Petrobras' tenders, joint activity in third countries, co-development of technologies, among other aspects. Diplomats recognized the possibility of mutual gains in technological transfer, given Petrobras' expertise in deep-water exploration and extraction, and Gazprom's know-how in natural gas extraction and delivery. The project of constructing a gas pipeline connecting extraction fields in Venezuela and Bolivia to major consuming areas in Southeastern Brazil and in Argentina drew attention not only of Gazprom, but also of Surgutneftegaz and Lukoil. Gazprom and Petrobras also signed a memorandum of understanding in 2007 that provided for cooperation in building gas and oil pipelines, joint-ventures in refining and natural gas liquefaction activities.

Political and economic divergences in goals, although not unsurmountable, did delay the fructification of bilateral projects. Brazilian officials stressed joint and mutually profitable development of technologies and processes, while the Russian side was keen at trading its techniques [5]. Regarding commercial operations, conflicting interests also were visible: while the Brazilians glimpsed the idea of expanding exports of biofuels at that time, the Russians perceived that fuel as a potential rival of crude oil and gas in global and domestic markets [5].

After an acquainting phase, the discovery of huge oil reserves in Brazilian pre-salt layer in late 2000s, Brazil has drew increasing attention from foreign players keen on entering the major Latin American market and, possibly, the biggest oil reserves in the region after Venezuela. Russian hydrocarbon enterprises have sought to assure a position in Brazil, making them as the main vector of Russian investments in Brazil.

At least four Russian companies (both private and state-owned ones) maintain or maintained a noticeable presence in the South American country: NK Rosneft, Lukoil, Gazprom and Neftegazgeodeziya. Among them, Rosneft has even established a local branch and, more importantly, has developed a significant project of oil extraction in Solimões Basin (Amazonas state) since 2013; in 2015, it has been the sole operator in the activity, by purchasing rights of local firms [19].

The Power Machines ("Silovye Machiny") concern has exported turbines to Brazil since the 1970s. In that decade, the Soviet equipment was exported for the hydropower plants of Capivara (São Paulo state) and Sobradinho (Bahia state). In the post-Soviet period, Power Machines has supplied equipment for the hydropower plants of Porto Góes (São Paulo state) and Passo São João (Rio Grande do Sul state). In 2010 the Russian corporation opened an office in São Paulo. In 2015, seeing the Latin American markets as promising, Power Machines acquired a fifty one per cent stake in Fezer, a Brazilian company based in the state of Santa Catarina and specialized in woodworking machinery as well as hydro turbine components [16]. Another Russian corporation, Energomashexport, has installed and launched two generators at Nova Aurora and two generators at Goiandira hydro power plants, both located in Goiás state [17].

10 During the viusit, Brazil expressed its support for Russian entry into the World Trade Organisation (WTO), while Moscow welcomed Brasilia's bid as a permanent member of the United Nations Security Council. 
Besides the provision of hydropower plant equipment, the bilateral relations in the energy sector are still far from reaching the expectations of both countries. In 2007, Gazprom and Stroytransgaz signed memorandums of mutual understanding with Brazilian Petrobras on exploration, production, transportation and commercialization of hydrocarbons. In 2011, Gazprom opened its office in Rio de Janeiro [18]. The construction of a transcontinental gas pipeline was discussed, but the project did not advance. After many years of contacts between Petrobras and Russian oil and gas corporations, Rosneft was finally able to start oil exploration in Brazil. This move was made possible because of growing cooperation between Rosneft and Petrobras. The promising Solimões project in the Amazon covers approximately 41.500 sq. $\mathrm{km}$ (16 license blocks). According to Rosneft, the project "establishes Rosneft in Brazil, a country with major upstream growth opportunities and synergies with Rosneft operations in Venezuela" [20]. This achievement, combined with the presence of Petrobras in Russia, might herald a new stage in the development of partnership. However, the favorable business climate was soon overcast by the corruption crisis in Brazil as well as economic and financial difficulties in Russia.

However, the volume of Russian investments in Brazilian energy sector remains very tiny if compared to other relevant players, such as the Americans, Chinese and other Europeans.

\section{The Brazilian-Russian energy dialogue in a broader view: the role of BRICS, interests and prospects}

Despite being net exporters of energy, especially when it comes to oil sector, Brazil and Russia do share a myriad of interests and may potentially enter into agreement on substantial issues. Sustaining international oil prices that at the same time surpass their own production costs and do not cause major damage to domestic prices of fuel suits their interests in relation to other players. This common objective is at odds with the interests of Saudi Arabian and other Gulf monarchies, which may endure much lower production costs, and of the United States, which has been developing unconventional forms of oil extraction, such as fracking. This has led to a boost in global supply of energy and has decisively impacted the formation of prices at the world level [6]. Moreover, Brazil and Russia do not directly compete in oil market: their exports target distinct regions, as Brazilian oil is sold to China, the United States, Chile, India and Spain, while Russia's production is sold mostly to European markets and China.

Global governance for energy is considerably underdeveloped if compared to other relevant issues. If direct interaction in specific projects between Brazilians and Russians has been remarkable since the Cold War, only since the 2000s officials from both nations have been raising and discussing relevant topics that may affect global energy security, both in bilateral meetings and in multilateral forums, notably in BRICS and, to a lesser extent, G20. Diplomats from both nations converge in basic principles of cooperation, such as the necessity of respecting national interests without meddling in the domestic affairs of other nations, the primacy of compromise solutions and the strengthening of multilateral mechanisms of decision (particularly the United Nations and its specialized agencies) under strict observance of International Law [7].

The idea of reducing foreign dependence of energy resources is seen in both nations not only under the superficial lenses of production and foreign trade, but also in 
terms of internalizing technologies that provide energy generation and delivery within their national boundaries at competitive prices. Also, they share the concept that energy should be object of their respective regional integration schemes; neighboring countries' output may serve as compliment to domestic supply and vice-versa. Transnational infrastructure is significantly much more developed in Eurasian area thanks to common Soviet past, although intra-South American links have been encouraged since the 1990s. Moreover, Russian enterprises tend to be more open to discuss potential technological transfer deals than their Western counterparts, what suits the Brazilian negotiators.

However, Brasilia and Moscow do differ on some substantial issues. Even though Russians and Brazilians are interested in increasing energy efficiency and reducing overdependency on one sole resource, the former tend to perceive energy security as stability in global markets, taking into consideration the interests of producers, consumers and transit countries [7], while the latter are more sensible to climate change issues and, therefore, eager to promote environment-friendly solutions.

Prospects of cooperation have been long stressed in treaties, official statements and political speeches of both nations' high-ranked authorities. Perhaps one central issue is nuclear energy, which has been under increasing attention of Brazilians authorities, after a brief but harsh period of unpredictability. The topic, which was discussed in successive occasions by Brazilian and Russian diplomats, is expected to return to the bilateral agenda over the next years. Technological collaboration in fossil fuels' exploration remains potential to be advanced, as soon as Brazilian investments in the sector resume after the mid-2010s economic recession. Due to their similar costs level of production, they also may devote some effort on stabilization (and even regulation) of oil global market by interacting with Organization of Petroleum Exporters Countries (OPEC), other non-OPEC countries, major transnational oil companies, and even opposing these players' activities.

Among other possible paths for cooperation rest on inter-companies co-work in third countries, inducement of higher aggregated-value in bilateral trade, stabilization of international trade routes and the establishment of an inclusive and fair global governance on energy.

The emergence of BRICS in the 2000s provided with a new room for debating political perspectives but also for envisaging potential projects, including in energy-related questions. Although the achievements of the group were quite meager and too specific over its first ten years of existence, it is true that the image of Brazil in Russia (and viceversa) has been highlighted, what may explain the surge of Russian investments in the Brazilian economy.

However, energy is yet highly underestimated in BRICS not due to perceived contradictory interests of its participating nations, but to the difficulty to tackle the issue in a global and holistic perspective. Although there are some institutions that address energy questions in a broader sense, they fail either in terms of global representativeness (as the case of International Energy Agency, which acts as a branch of Western-dominated Organization for Economic Cooperation and Development) or scope (such as the International Renewable Energy Agency, which count with genuine global representation, but its sector focus remains limited to regulation of alternative sources).

BRICS nations do engage in energy issues, but they prefer proceeding it in a bilateral or intra-regional basis. Beyond the burgeoning contracts being promoted between Russia 
and China since 2014 in oil and gas sector and, to a lesser extent, Russia and India in the joint-ventures in gas industry in the Sakhalin, the Shanghai Cooperation Organization (SCO), which encompasses the three counties, has been active on promoting energy debates, including the 'Energy Club' [16].

In a contextual prism, Brazilian-Russian projects unfolded the densification of diplomatic and trade interaction since mid-2000s. Many topics discussed especially during Inácio da Silva's second term (2007-2010) matured and produced effects during Rousseff's first term (2011-2014). The political and economic turmoil in the South American country after 2015 did effect the evolvement of government-led projects, but did not jeopardize the activities of Russian businesses in Brazilian soil, as seen in the previous section. The level of bilateral relations will depend not only on the prevalent political will within the new elect president, but also the ability of Jair Bolsonaro's administration (entered in office since January, 2019) in overcoming economic crisis which affected many projects, including in energy sector.

Even though the first declarations indicated that the new president will strive to improve relations with the United States and review the relationship with pertinent partners, especially China, it is still very unclear the role of Russia on the Brazilian foreign policy radar. Due to budgetary cuts, strived domestic policy and uncertainness within the formulation of foreign policy, links with Russia and other emerging powers (especially in Eurasia) may wane, thus restoring Fernando Collor de Mello's and Henrique Cardoso's agendas too focused in primary trade, rather than promotion of innovative forms of cooperation.

\section{Concluding remarks}

In a pure quantitative and superficial analysis, Brazil and Russia share many broad similarities on energy issues that would put them more as competitors than friends: both are net exports of fossil fuels while geographic distance would further inhibit economic interaction. However, a deeper investigation suggests exactly an opposite conclusion.

Even in oil sector, stabilizing global oil prices and securing international trade routes is generally desired among both nations' governments and companies, what shall be addressed in multilateral forums, including BRICS and the United Nations. There is even room for mutually benefic cooperation between major petrol giants Petrobras and Rosneft, given their performance in certain domains such as deep-water exploration and refining. They are also wary of competition of other lower-cost producers in the Persian Gulf and the emergence of non-traditional forms of extraction, such as fracking in North America. Complementarity is much more apparent due to their expertise in distinct energy sources.

Uncertainties and inconsistencies in policy planning and implementation, though, is a major hindrance for a successful interaction not only between Brazil and Russia, but for their own strategies of ensuing energy security at home and of projecting power and influence overseas, especially in the case of Brazil.

\section{References}

1. Fuser, I. (2013), Energia e Relaçoes Internacionais (Energy and International Relations), Saraiva, São Paulo, Brazil. 
2. Oliveira, L. K. de (2012), Energia como recurso de poder na política internacional: geopolítica, estratégia e o papel do centro de decisão energética (Energy as a power resource in an international policy: geopolitics, strategy and role of energy decision-making center), Doctoral dissertation, Programa de Pós-Graduação em Estudos Estratégicos Internacionais, Porto Alegre, Brazil.

3. Hoff, C. R. (2016), "Petrobras still matters for the Brazilian economy", Panorama Internacional FEE, vol. 2, 1, pp. 15-22.

4. Cervo, A. (2008), História da Política Exterior do Brasil [History and Foreign Policy of Brasil], UnB, Brasília, Brazil.

5. Jubran, B. (2012), Master thesis. Brasil e Rússia: política, comércio, ciência e tecnologia entre 1992 e 2010 [Brasil and Russia: politics, commerce, Science and technology since 1992 to 2010], Programa de Pós-Graduação em Relações Internacionais, Universidade Federal do Rio Grande do Sul, Porto Alegre, Brazil.

6. Leães, R. F. (2016), “The multifaceted nature of oil dynamics”, Panorama Internacional FEE, vol. 2, no. 1, pp. 8-14.

7. Panova, V. (2015), “Global'noe upravlenie v sfere energetiki: mif ili real'nost'?" [Development of forms of collective management: Global energy governance: myth or reality?], Vestnik mezhdunarodnykh organizatsii, vol. 10, no. 1, pp. 143-158. (In Russian)

8. Brands, H. (2010), Dilemmas of Brazilian Grand Strategy. U. S. Army War College: Institute of Strategic Studies, Carlisle, USA.

9. "Russia's energy strategy until 2035" (2017), Ministry of Energy of the Russian Federation, available at: http://www.energystrategy.ru/ab_ins/source/ES-2035_09_2015.pdf (accessed: 21.11.2018).

10. "Statistics of foreign trade of the Russian Federation" (2018), Federal Customs Service, 12.02, available at: http://www.customs.ru/index.php?option=com_content\&view=article\&id=26274:2016 (accessed: 21.11.2018).

11. EU reaches gas deal with Ukraine, available at: http://news.bbc.co.uk/2/hi/europe/8179461.stm (accessed: 21.11.2018).

12. British Petroleum Statistical Review of World Energy, 2018, available at: https://www.bp.com/content/dam/bp/business-sites/en/global/corporate/pdfs/energy-economics/statistical-review/bp-stats-review-2018-full-report.pdf (accessed: 21.11.2018).

13. Eurostat, 2017, available at: http://ec.europa.eu/eurostat/statistics-explained/images/c/c8/Main_origin_of_primary_energy_imports \%2C_EU-28\%2C_2006-2016_\%28\%25_of_extra_EU-28_imports \%29. png (accessed: 21.11.2018).

14. Plano Nacional de Energia. Retrospectiva Empresa de Pesquisa Energética [National Energy Plan. Retrospective Energy Research Company], available at: http://epe.gov.br/en/about-epe/who-we-are (accessed: 21.11. 2018).

15. "Agência Nacional de Petróleo" [National Petroleum Agency], Anuário Estatístico 2018, [Segunda Seção], available at: http://www.anp.gov.br/images/publicacoes/anuario-estatistico/2018/textos/Secao2.pdf (accessed: 21.11.2018).

16. "Structure of the Shanghai Cooperation" (2017), Shanghai Cooperation Organization, 01.09, available at: http://eng.sectsco.org/structure/20170109/190929.html (accessed: 21.11.2018).

17. "Power Machines continuing to strengthen positions in Latin America", available at http://www. power-m.ru/en/press-center/news/power-machines-continuing-to-strengthen-positions-in-latin-ameri$\mathrm{ca} /$ (accessed: 21.11.2018).

18. Trade and Economic Cooperation between Russia and Brazil, February 20, 2013, available at: http:// government.ru/en/info/419/ (accessed: 21.11.2018).

19. Rosneft Becomes the Holder of $100 \%$ of the Solimoes Project, May 18, 2015, available at: http://www. rosneft.com/news/pressrelease/18052015.html (accessed: 21.11.2018).

20. Rosneft Closes the Deal with PetroRio and Becomes the Holder of $100 \%$ of the Solimoes Project, October 13, 2015, available at: http://www.rosneft.com/news/pressrelease/13102015.html (accessed: 21.11.2018).

21. Empresa de Pesquisa Energética [Energy Research Company], available at: http://epe.gov.br/en/ about-epe/who-we-are (accessed: 21.11.2018).

Author's information:

Received: January 22, 2019

Accepted: February 14, 2019

Bruno Mariotto Jubran — PhD of Internation Strategic Studies; mariotto.bruno@gmail.com

Victor Jeifets — Dr. of Science (Hist.), Professor; jeifets@gmail.com 